\title{
Repair bond strength of composite resin to zirconia restorations after different thermal cycles
}

\author{
Serkan Çınar, Ömer Kırmalı* \\ Department of Prosthodontics, Faculty of Dentistry, Akdeniz University, Antalya, Turkey
}

\begin{abstract}
PURPOSE. This in vitro study investigated the repair bond strength of the zirconia ceramic after different aging conditions. MATERIALS AND METHODS. In order to imitate the failure modes of veneered zirconia restorations, veneer ceramic, zirconia, and veneer ceramic-zirconia specimens were prepared and were divided into 4 subgroups as: control $\left(37^{\circ} \mathrm{C}\right.$ distilled water for 24 hours $)$ and $3000,6000,12000$ thermal cycling groups $(n=15)$. Then, specimens were bonded to composite resin using a porcelain repair kit according to the manufacturer recommendation. The repair bond strength (RBS) test was performed using a universal testing machine $(0.5 \mathrm{~mm} /$ min). Failure types were analyzed under a stereomicroscope. Two-way ANOVA and Bonferroni test were used for statistical analysis. RESULTS. The RBS values of zirconia specimens were statistically significant and higher than veneer ceramic and veneer ceramic-zirconia specimens in control, 3000 and 6000 thermal cycling groups $(P<.05)$. When 12000 thermal cycles were applied, the highest value was found in zirconia specimens but there was no statistically significant difference between veneer ceramic and veneer ceramic-zirconia specimens $(P>$.05). Veneer ceramic specimens exhibited cohesive failure types, zirconia specimens exhibited adhesive failure types, and veneer ceramic-zirconia specimens exhibited predominately mixed failure types.
\end{abstract}

CONCLUSION. Thermal cycling can adversely affect RBS of composite resin bınded to level of fractured zirconia ceramics. [J Adv Prosthodont 2019;11:297-304]

KEYWORDS: Zircornia; Thermal cycling; Repair bond strength; Composite resin; Porcelain repaire systems

\section{INTRODUCTION}

Zirconia materials with high fracture resistance have become very prevalent in today's dentistry and they have started to substitute for traditional metal-ceramic restorations. ${ }^{1,2}$ Zirconia has good adaptability to thermal changes and high resistance to corrosion, abrasion, and chemicals. Besides, it has a quite opaque appearance due to its dense crystalline phase. Therefore, appropriate veneering ceramics are necessary to be coated in order to provide a natural tooth-like translucency and enhance the aesthetics of restoration. ${ }^{3}$ The

\section{Corresponding author:}

Omer Kirmali

Department of Prosthodontics, Faculty of Dentistry, Akdeniz University,

Dumlupınar Boulevard, 07058 Campus, Antalya, Turkey

Tel. +902422274400-2935: e-mail, omerkrml@ymail.com

Received August 5, 2019 / Last Revision October 16, 2019 / Accepted

October 29, 2019

(C) 2019 The Korean Academy of Prosthodontics

This is an Open Access article distributed under the terms of the Creative Commons Attribution Non-Commercial License (http://creativecommons. org/licenses/by-nc/4.0) which permits unrestricted non-commercial use, distribution, and reproduction in any medium, provided the original work is properly cited. most common problem of restorations made with zirconia is the separation of veneering ceramics from zirconia. ${ }^{4,5}$ Differences in the expansion coefficient of veneering ceramics and zirconia, unsuitable designs, improper dental preparations, premature contacts, laboratory faults, and physical trauma can cause veneer ceramic chipping or breakage. This situation may aesthetically and functionally disturb the dentist and patient. ${ }^{6}$

Prosthesis should be remade when the veneer ceramic is broken. However, it can be repaired in the mouth in order to avoid the increase of cost and time, need for laboratory work, difficulty of dismantling full ceramic restorations, and discomfort of patient. Duration of the restoration can be extended with less risk by using this method. ${ }^{7-9}$ If restoration functions can be maintained and does not need to be renewed for another reason, intraoral repair provides an alternative treatment. Composite resins are frequently used for repair of fractures in mouth. ${ }^{7,10}$ The connection between repair material and fracture surface is provided with a chemical and micromechanical connection. ${ }^{11,12}$ In order to increase the bond strength, surface treatments can be performed such as sandblasting with aluminum oxide $\left(\mathrm{Al}_{2} \mathrm{O}_{3}\right)$ particles, ${ }^{13}$ acid application, ${ }^{14}$ roughening with diamond burs, ${ }^{15}$ laser applica- 
tion, ${ }^{16}$ sandblasting with silica coated particles, ${ }^{17}$ and silane application. $^{12}$

Thermal aging is an important method applied to materials to simulate the oral environment. Many studies have reported that the durability of dental materials decreases when they are used in mouth for a certain period of time. ${ }^{18,19}$ The aim of this study is to evaluate the effect of different thermal cycle applications on RBS between composite materials used for the repair of zirconia-based veneer ceramic restorations and fracture surfaces. The null hypothesis of the present study was that there are no differences between short- and long-term cycles RBS.

\section{MATERIALS AND METHODS}

The brand names, codes, and manufacturer details of all tested materials are shown in Table 1.

A total of 180 disc shaped specimens $(7 \mathrm{~mm}$ in diameter and $3 \mathrm{~mm}$ in height) were prepared to test the RBS of veneer ceramic repair system to various ceramic surfaces treated with different methods (Fig. 1). The specimens were divided into 3 groups of 60 discs each.

Group I: Test surfaces of the specimens consisted of zirconia (Zirconia 100\%).

Group II: Test surfaces of the specimens consisted of veneering ceramic (Veneer ceramic 100\%).

Group III: Test surfaces of the specimens consisted of $50 \%$ veneering ceramic and $50 \%$ zirconia.

Zirconia specimens with three different shapes were produced for the specimens and the target size was reached by sintering according to the manufacturer's recommendations. The target sizes were $7 \mathrm{~mm}$ in diameter and $3 \mathrm{~mm}$ in height for zirconia specimens (Group I), $7 \mathrm{~mm}$ in diameter and $1.5 \mathrm{~mm}$ in height for veneer ceramic specimens (Group II). Veneer ceramic-zirconia specimens were $7 \mathrm{~mm}$ in diameter and $3 \mathrm{~mm}$ in height with the interface in the middle (Group III). Subsequently, $1.5 \mathrm{~mm}$ thick veneering veneer ceramic was applied to the test surface of zirconia discs in Group I and Group II. They were put into a vacuum veneer ceramic furnace that was be programmed to $760^{\circ} \mathrm{C}$.
In order to simulate fracture types, Group I, Group II, and Group III were formed. Each group consisted of 60 specimens. These groups were divided into 4 subgroups: control (no thermal cycle), 3000, 6000, and 12000 thermal cycles. Therefore, a total of 12 groups were obtained ( $\mathrm{n}=$ 15). These subgroups were named as control, $3000 \mathrm{~T}, 6000$ $\mathrm{T}$, and $12000 \mathrm{~T}$. All specimens were placed in the apparatus prepared according to the number of thermal cycling. Afterwards, 3000, 6000, and 12000 thermal cycles were applied to the specimens in the thermal cycle device at 5 $55^{\circ} \mathrm{C}$ with dwell and transfer times of 30 seconds each (Fig. 2). Control group specimens were stored in distilled water at $37^{\circ} \mathrm{C}$ for 24 hours.

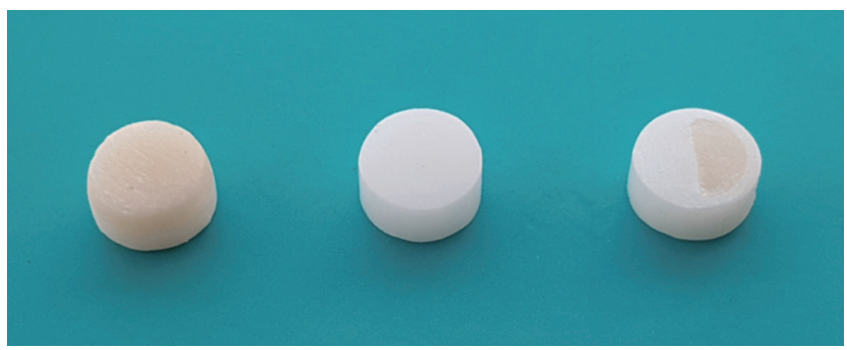

Fig. 1. Tested specimens in the study. Veneering ceramic, zirconia, and 50\% zirconia - 50\% veneering ceramic.

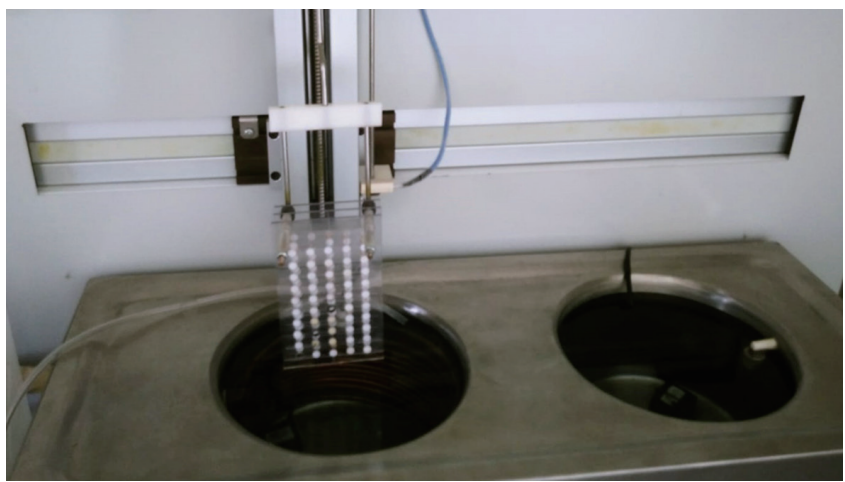

Fig. 2. All specimens were placed in the apparatus prepared according to the number of thermal cycling.

Table 1. Experimental materials and their characteristics

\begin{tabular}{lll}
\hline Product & Manufacturer & Lot numbers \\
\hline Zirconia & Nacera, Doceram, Germany & 5064855 \\
Veneer ceramic & Noritake CZR, Kuraray, Japan & DWAIH \\
Repair system & Clearfil Repair, Kuraray, Japan & 000049 \\
Acid & K-Etchant Gel, Kuraray, Japan & BP0087 \\
Primer & Clearfil Se Bond, Primer, Kuraray, Japan & CB0279 \\
Silane & Clearfil Porcelain Bond Activator, Kuraray, Japan & CE0042 \\
Bond & Clearfil Se Bond Bond, Kuraray, Japan & C50447 \\
Diamond bur & Bosphorus, Tekmetal, Turkey & $160311-05$ \\
Composite resin & GrandioSo, Voco, Germany & 1307550 \\
\hline
\end{tabular}


The surfaces of all group specimens were roughened for 10 seconds by using a $120 \mu \mathrm{m}$ diamond bur (Bosphorus, Istanbul, Turkey) with a high-speed water cooled clinical aerator to simulate the clinical situation. Afterwards, the materials included in the repair kit (Kuraray Clearfil Repair Kit, Okayama, Japan) were then applied in the order recommended by the manufacturer. Phosphoric acid (K-Etchant Gel) was applied to the all surfaces as a first step and, after waiting for 5 seconds, it was washed with water and dried with oil-free air. Clearfil SE Bond Primer and Clearfil Porcelain Bond Activator were mixed in a 1:1 ratio and applied for 5 seconds. Clearfil SE Bond was then applied and light-cured for 10 seconds. The same surface treatments were applied to ensure standardization for each group of specimens.

To standardize the bonding surface, a tygon tube with 3 $\mathrm{mm}$ diameter and $3 \mathrm{~mm}$ height was placed at the center of each specimen. The composite material (GrandioSo, Voco, Cuxhaven, Germany) was then placed into the tubes and photopolymerized for 40 seconds using a light-polymerizing unit (Valo Cordless, Ultradent, South Jordan, UT, USA). After polymerization, the tygon tubes were gently detached using a scalpel and all specimens were subjected to RBS test. The specimens were embedded in acrylic resin (Imicryl, Konya, Turkey) molds and placed into the universal testing machine (DCS 500, Shimadzu Corp., Kyoto, Japan). RBS tests were performed at a $0.5 \mathrm{~mm} / \mathrm{min}$ crosshead speed to measure the repair bond strength values (Fig. 3). The tester blade was placed at an angle of $90^{\circ}$ with the bonding surface and the forces at the time of separation were measured in Newton $(\mathrm{N})$. The RBS values obtained in $\mathrm{N}$ were converted to MPa by dividing the bonding area of the composite resin.

$$
\begin{aligned}
& \text { Shear resistance }(\mathrm{MPa})=\operatorname{Load}(\mathrm{N}) / \text { Area }\left(\mathrm{mm}^{2}\right) \\
& \text { Area }=\pi \times \mathrm{r}^{2} \\
& \mathrm{r}=\text { Radius of bonding surface. }
\end{aligned}
$$

The fracture patterns of all specimens after RBS testing were examined under stereomicroscope (Zeiss, Jena, Germany) at $\times 15$ magnification. These examinations revealed adhesive (between composite resin and ceramic surface), cohesive (within the ceramic or composite resin), and mixed (both fracture types) failure modes.

Data were analyzed using IBM SPSS Version 22 (IBM, Armonk, NY, USA). Levene test was applied to determine homogeneity of variances. Two-way ANOVA test was done to determine whether there is a statistical difference between the effect of different ceramic surfaces and different thermal cycling applications on bond strength (Table 2). Bonferroni test was used for multiple comparisons. Results were evaluated with confidence interval $(95 \%)$ and level of significance $(P<.05)$ (Table 3$)$.

\section{RESULTS}

Table 4 shows the means and standard deviations values of all groups. The highest and lowest RBS were obtained in control zirconia and 12000 T veneer ceramic groups, respectively. When we examined the effect of thermal cycling on

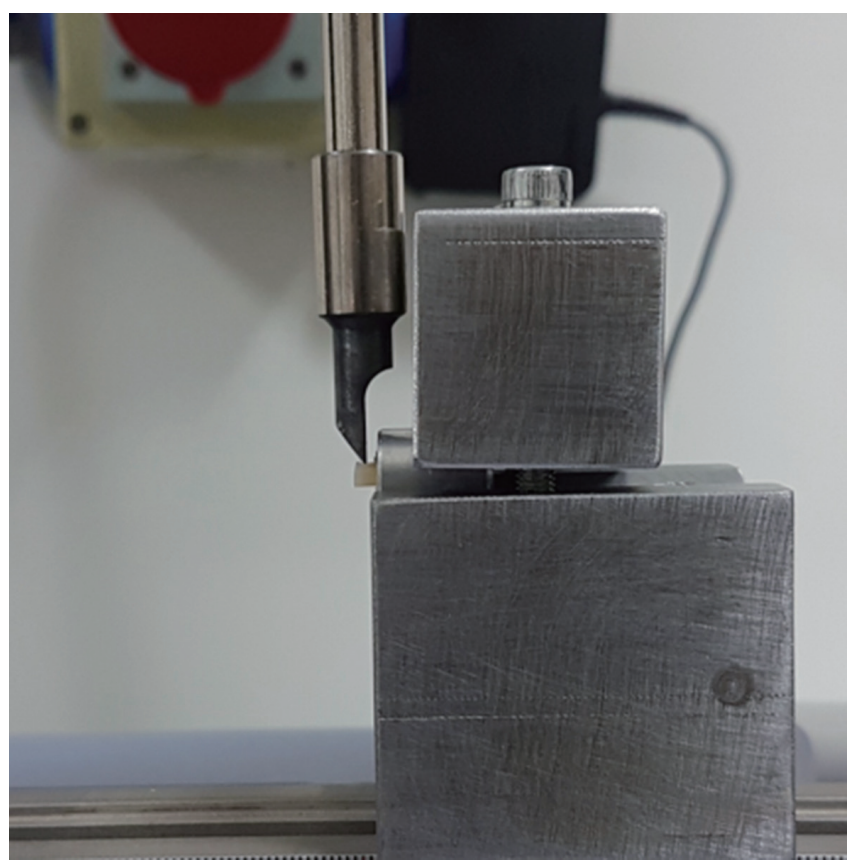

Fig. 3. Illustration of RBS test of the specimens.

Table 2. The results of two-way ANOVA on the repair bond strength (MPa)

\begin{tabular}{lrrrrrr}
\hline Source & \multicolumn{1}{c}{ SS } & df & MS & F & Sig. & $P$ \\
\hline Thermal Cycles (TC) & 254.940 & 3 & 84.980 & 11.057 & 0.000 & .165 \\
Ceramic Material (CM) & 407.148 & 2 & 203.574 & 26.488 & 0.000 & .240 \\
TC $\times$ CM & 97.587 & 6 & 16.265 & 2.116 & 0.054 & .070 \\
Error & 1291.154 & 168 & 7.685 & & \\
Total & 35673.835 & 180 & & & \\
\hline
\end{tabular}

SS: Sum of square, MS: Mean square, df: Degree of freedom, TC $\times$ CM: Effect of the interaction between thermal cycle and ceramic material 
Table 3. Pairwise comparison of 4 different thermal cycles applications at 0.001 significance level

\begin{tabular}{|c|c|c|c|c|c|c|c|}
\hline \multirow{2}{*}{ Group } & & & \multirow{2}{*}{ MD } & \multirow{2}{*}{ SD } & \multirow{2}{*}{ Sig. ${ }^{b}$} & \multicolumn{2}{|c|}{ 95\% Confidence Interval for Difference } \\
\hline & & & & & & Lower bound & Upper bound \\
\hline \multirow{6}{*}{ Control } & \multirow{2}{*}{ Veneer ceramic } & Zirconia & $-4.396^{\star}$ & 1.012 & 0.000 & -6.844 & -1.948 \\
\hline & & Veneer ceramic - Zirconia & -1.581 & 1.012 & 0.360 & -4.029 & 0.867 \\
\hline & \multirow{2}{*}{ Zirconia } & Veneer ceramic & $4.396^{\star}$ & 1.012 & 0.000 & 1.948 & 6.844 \\
\hline & & Veneer ceramic - Zirconia & $2.815^{\star}$ & 1.012 & 0.018 & 0.367 & 5.263 \\
\hline & \multirow{2}{*}{$\begin{array}{l}\text { Veneer ceramic - } \\
\text { Zirconia }\end{array}$} & Veneer ceramic & 1.581 & 1.012 & 0.360 & -0.867 & 4.029 \\
\hline & & Zirconia & $-2.815^{\star}$ & 1.012 & 0.018 & -5.263 & -0.367 \\
\hline \multirow{6}{*}{ 3000T } & \multirow{2}{*}{ Veneer ceramic } & Zirconia & $-4.567^{\star}$ & 1.012 & 0.000 & -7.015 & -2.119 \\
\hline & & Veneer ceramic - Zirconia & -0.324 & 1.012 & 1.000 & -2.772 & 2.124 \\
\hline & \multirow{2}{*}{ Zirconia } & Veneer ceramic & $4.567^{\star}$ & 1.012 & 0.000 & 2.119 & 7.015 \\
\hline & & Veneer ceramic - Zirconia & $4.243^{*}$ & 1.012 & 0.000 & 1.795 & 6.691 \\
\hline & \multirow{2}{*}{$\begin{array}{l}\text { Veneer ceramic - } \\
\text { Zirconia }\end{array}$} & Veneer ceramic & 0.324 & 1.012 & 1.000 & -2.124 & 2.772 \\
\hline & & Zirconia & $-4.243^{*}$ & 1.012 & 0.000 & -6.691 & -1.795 \\
\hline \multirow{6}{*}{$6000 \mathrm{~T}$} & \multirow{2}{*}{ Veneer ceramic } & Zirconia & $-4.257^{\star}$ & 1.012 & 0.000 & -6.705 & -1.809 \\
\hline & & Veneer ceramic - Zirconia & -0.666 & 1.012 & 1.000 & -3.114 & 1.782 \\
\hline & \multirow{2}{*}{ Zirconia } & Veneer ceramic & $4.257^{\star}$ & 1.012 & 0.000 & 1.809 & 6.705 \\
\hline & & Veneer ceramic - Zirconia & $3.591^{*}$ & 1.012 & 0.002 & 1.143 & 6.039 \\
\hline & \multirow{2}{*}{$\begin{array}{l}\text { Veneer ceramic - } \\
\text { Zirconia }\end{array}$} & Veneer ceramic & 0.666 & 1.012 & 1.000 & -1782 & 3.114 \\
\hline & & Zirconia & $-3.591^{*}$ & 1.012 & 0.002 & -6.039 & -1.143 \\
\hline \multirow{6}{*}{$12000 T$} & \multirow{2}{*}{ Veneer ceramic } & Zirconia & -0.674 & 1.012 & 1.000 & -3.122 & 1.774 \\
\hline & & Veneer ceramic - Zirconia & -0.124 & 1.012 & 1.000 & -2.572 & 2.324 \\
\hline & \multirow{2}{*}{ Zirconia } & Veneer ceramic & 0.674 & 1.012 & 1.000 & -1.774 & 3.122 \\
\hline & & Veneer ceramic - Zirconia & 0.550 & 1.012 & 1.000 & -1.898 & 2.998 \\
\hline & \multirow{2}{*}{$\begin{array}{l}\text { Veneer ceramic - } \\
\text { Zirconia }\end{array}$} & Veneer ceramic & 0.124 & 1.012 & 1.000 & -2.324 & 2.572 \\
\hline & & Zirconia & -0.550 & 1.012 & 1.000 & -2.998 & 1.898 \\
\hline
\end{tabular}

* The mean difference is significant at the .05 level.

${ }^{\mathrm{b}}$ Adjustment for multiple comparisons: Bonferroni.

Table 4. Mean RBS (MPa) and standard deviation (SD) values

\begin{tabular}{|c|c|c|c|c|}
\hline Thermal cycle & Groups & Mean (MPa) & Standard deviation & $\mathrm{N}$ \\
\hline & Veneer ceramic & 13.06 & 2.55 & 15 \\
\hline \multirow[t]{3}{*}{ Control } & Zirconia & 17.45 & 3.50 & 15 \\
\hline & Veneer ceramic - Zirconia & 14.64 & 3.49 & 15 \\
\hline & Veneer ceramic & 12.39 & 1.85 & 15 \\
\hline \multirow[t]{3}{*}{ 3000T } & Zirconia & 16.96 & 3.82 & 15 \\
\hline & Veneer ceramic - Zirconia & 12.72 & 1.38 & 15 \\
\hline & Veneer ceramic & 12.17 & 2.93 & 15 \\
\hline \multirow[t]{3}{*}{$6000 T$} & Zirconia & 16.43 & 2.08 & 15 \\
\hline & Veneer ceramic - Zirconia & 12.84 & 1.98 & 15 \\
\hline & Veneer ceramic & 11.50 & 1.79 & 15 \\
\hline \multirow[t]{2}{*}{$12000 T$} & Zirconia & 12.18 & 3.89 & 15 \\
\hline & Veneer ceramic - Zirconia & 11.63 & 2.43 & 15 \\
\hline
\end{tabular}

Statistical differences between the groups were considered significant compared to $P<.05$. 
the RBS between veneer ceramic specimens and repair composite, the highest value was obtained in control group and the lowest value was taken in $12000 \mathrm{~T}$ group. Although the RBS values of control group were higher than the RBS of $3000 \mathrm{~T}$ and $6000 \mathrm{~T}$ groups, no statistically significant difference was found among control, 3000 T, 6000 T, and 12000 T groups $(P>.05)$.

Among zirconia specimens, the highest value was observed in control group and the lowest value was found in $12000 \mathrm{~T}$ group. The RBS values of control group were higher than the RBS values of $3000 \mathrm{~T}$ and $6000 \mathrm{~T}$ groups, but there was no significant difference among these groups. $12000 \mathrm{~T}$ group had significantly lower binding values than control, $3000 \mathrm{~T}$, and 6000 T groups.

Within the veneer ceramic-zirconia specimens, the highest RBS value was obtained in control group. The lowest value was found in $12000 \mathrm{~T}$ group and the difference was statistically significant. Although the RBS values of control group were higher than the RBS values of 3000 T and 6000 T groups, no significant difference was observed among these groups. There was also no significant difference among 3000 T, 6000 T, and 12000 T groups.

When the RBS with the repair composite is examined within control, $3000 \mathrm{~T}$, and $6000 \mathrm{~T}$ groups, there was no statistically significant difference between veneer ceramic and veneer ceramic-zirconia specimens, whereas zirconia specimens showed significantly higher values.

In $12000 \mathrm{~T}$ group, the highest RBS value was found in zirconia specimens and the lowest value was in veneer ceramic specimens. However, there was no significant difference among veneer ceramic, zirconia, and veneer ceramic-zirconia specimens.

Veneer ceramic specimens had only cohesive failures and zirconia specimens exhibited only adhesive failures. In veneer ceramic-zirconia specimens, adhesive and higher mixed type failures were observed (Fig. 4).

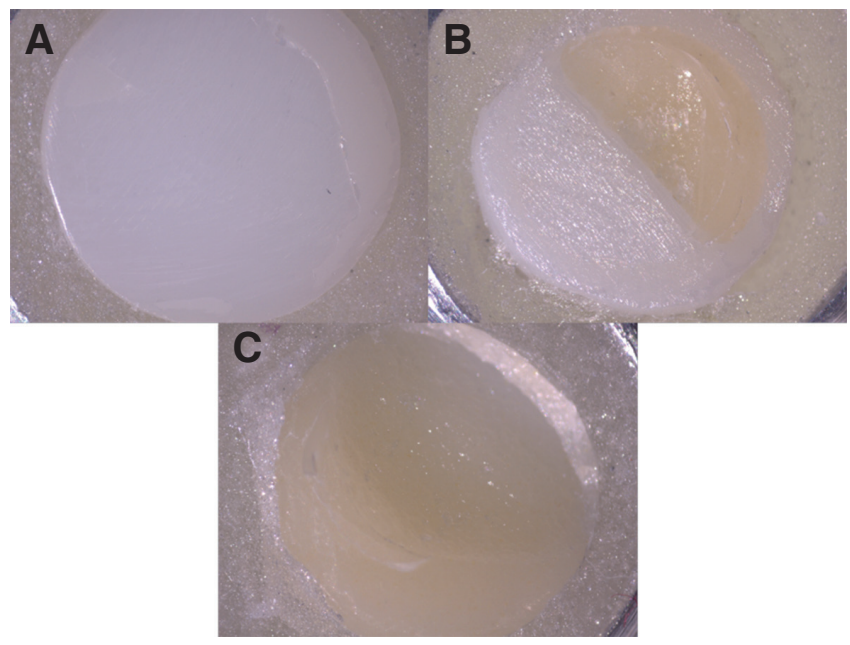

Fig. 4. Stereomicroscope images of the specimens after RBS test: (A) adhesive failure, (B) mix failure, (C) cohesive failure, $\times 32$ magnification.

\section{DISCUSSION}

In the repair process made with composite resin, the hypothesis that the lowest RBS values will be seen in fractures where the veneer ceramic is separated and only the zirconia remains is rejected, in line with the findings of our study. The hypothesis that RBS values between composite resins and ceramics will decrease as the number of thermal cycles increases is partially accepted. Applying 12000 thermal cycles significantly reduced bond strength in veneer ceramic-zirconia and zirconia specimens, but the decrease in veneer ceramic specimens did not make a statistically significant difference.

Many studies have been conducted on the bond strength between zirconia and veneer ceramic. However, fracture of the veneer ceramic remains as a frequently reported complication. ${ }^{420-22}$ Adding new veneer ceramic to the broken restoration is almost impossible in the mouth due to the structure of veneer ceramic. Therefore veneer ceramic fracture is a difficult situation for both the patient and the dentist. ${ }^{23}$ When the fracture area is small, repair can be performed in the mouth by using composite resins. This method is often preferred because of its ease of application, ability to be performed in one session, having different colour options, valid aesthetic appearance, and being economical. Recent developments in adhesive systems provide successful results. ${ }^{24,25}$

The repair process was based on the macro mechanical bond between the repair material and fracture surface in previous years. ${ }^{26}$ It is built on chemical and micro-mechanical connections as well as the connection strength of surface treatment in recent years. ${ }^{27,28}$ Hydrofluoric acid (HF) roughening process is one of the most commonly used methods to increase the bond strength between ceramic surface and resin..$^{29,30}$ It dissolves the glassy and crystalline content of ceramics and increases micro retention. HF acid process is effective in silica-based ceramics. Since zirconia and alumina ceramics are not silica-based, they are resistant to acid application. ${ }^{14}$ Shiu et al. ${ }^{31}$ applied various surface treatments on feldspathic ceramic in order to evaluate the RBS of resin cement to feldspathic ceramic. They obtained the highest bond strength values in specimens with $10 \% \mathrm{HF}$ acid applied. Similarly, Aky1 et al. ${ }^{32}$ got the highest bond strength between feldspatic ceramic and repair composite resin in HF acid applied specimens. Contrary to these studies, it has been reported that application of HF acid to veneer ceramic surface may cause premature failure when it is not used in ideal proportions and time. A porous structure on ceramic surface may be formed. ${ }^{6}$ In addition, it should be applied carefully because it has harmful effects on skin, soft tissues, and lungs by inhalation. ${ }^{33}$ In some repair sets, $35-40 \%$ phosphoric acid $\left(\mathrm{H}_{3} \mathrm{PO}_{4}\right.$ acid) is added as an alternative to $\mathrm{HF}$ acid. ${ }^{17}$ Leibrock et al. ${ }^{34}$ analyzed RBS between veneer ceramic and repair composite after thermal cycling and mechanical loading and found no significant difference between systems using $\mathrm{H}_{3} \mathrm{PO}_{4}$ acid or $\mathrm{HF}$ acid. Because of its chemically aggressive nature, HF should be avoided and replaced with $\mathrm{H}_{3} \mathrm{PO}_{4}$ acid, which is not harmful 
to tissues and produces the same effects when used with silane agent. In this study, $\mathrm{K}$-etchant gel with $40 \% \mathrm{H}_{3} \mathrm{PO}_{4}$ acid was applied to the specimen surfaces according to the usage advices of the company.

When the fracture site of the restoration is to be repaired with composite resin, the surface roughening process is performed with diamond burs, which is a widely used method to increase mechanical retention and to remove veneer ceramic structure and contaminated area. ${ }^{15,35}$ Şen $e t$ al..$^{36}$ worked on the surface roughening treatments that are applied with sandblasting, acid, and diamond bur. They examined the effect of veneer ceramic repair materials on the bond strength. The highest bond values were obtained in the acid applied groups. However, they did not find a significant difference in the bonding forces obtained after acid applying and diamond bur roughening, and reported that roughening of the veneer ceramic with diamond bur is a more practical method. Kirmali et al. ${ }^{35}$ found high bond strength of composite resins after roughening of zirconia ceramics with diamond burs. In this study, surface roughening process with a diamond bur was applied to the specimens as described in the instructions of the repair kit.

The chemical bond between metal or ceramic surfaces and the resin is formed by silanes or phosphate monomers. ${ }^{37}$ Silane application is the main factor for bonding the composite resin onto the ceramic surface. ${ }^{38}$ Silane increases the wetness of the surface, allowing the low viscosity resin to flow more easily and increasing micromechanical retention. $^{39,40}$ After the surface treatments, surface should be wetted with 10-methacryloxidecyl dihydrogen phosphate (MDP) monomer to increase the bond strength between zirconia surface and the repair composite. ${ }^{41,42}$ Since MDP monomer is water resistant, it provides stable adhesion by showing resistance to hydrolysis during different aging methods. ${ }^{43}$ Therefore, in our study, Clearfil Repair kit was used, which includes silane and MDP based adhesive.

Many studies have reported that the durability of dental materials decreases when they are used in mouth for a certain period of time. There are aging methods applied to the materials to mimic the oral environment. ${ }^{18,19}$ Long-term storage in water with constant temperature and thermal cycling are clinical aging parameters and they are often used when measuring the bond strength of resins. ${ }^{19,44,45}$ Passia et al. ${ }^{46}$ reported a significant decrease in tensile bond strength values between zirconia and adhesive systems after thermal cycling. Özcan and Vallittu ${ }^{14}$ evaluated the effect of acid, sandblasting, and silica coating on bond strength of BISGMA-based resin with six different ceramics and stated that the application of thermal cycle significantly reduced bond strength in all groups. D'Amario et al. ${ }^{18}$ reported that the application of thermal cycling significantly reduced the bond strength between zirconia and resin cement. Similarly, in this study, statistically significant lower values were obtained for the bonding forces between zirconia specimens and composite resin in $12000 \mathrm{~T}$ group than the control group. Özcan et al. ${ }^{15}$ compared the durability of repair bond strength of a resin composite with reinforced ceramic. They applied 12000 thermal cycles to some of the specimens after 150 days of water storage. Compared to other repair kits in their study, Clearfil repair kit showed significantly lower bond strength in thermal cycled specimens. The use of micro tensile test, various specimen sizes, and prolonged storage of specimens can be the reasons of differences in results. We obtained higher bond strength from the veneer ceramic specimens in control group than the veneer ceramic specimens in $12000 \mathrm{~T}$ group, but the difference was not statistically significant.

Kamada et al. ${ }^{47}$ evaluated the effect of different surface treatments on the bond strength between ceramic (Cerec 2) and resin luting agents. They showed that there was no significant difference between water storage $\left(37^{\circ} \mathrm{C}, 24\right.$ hours) and 20000 thermal cycle applications for the values of RBS of $\mathrm{H}_{3} \mathrm{PO}_{4}$ acid-silane applied specimens. Matsumura et al. ${ }^{48}$ roughened the feldspatic veneer ceramic surface with $50 \mu \mathrm{m}$ $\mathrm{Al}_{2} \mathrm{O}_{3}$ powder and applied resin cement. They reported that the bond strength values decreased after thermal cycling in samples treated with Clapearl DC resin cement and Clearfil Porcelain Bond Activator, but the difference from the specimens without thermal cycling was not significant. Appeldoorn et al. ${ }^{7}$ evaluated the relationship between veneer ceramic and composite resin. Half of the specimens were kept in water at $37^{\circ} \mathrm{C}$ for 24 hours, the other half stayed in water for 3 months and then were applied 2500 thermal cycles $\left(5-55^{\circ} \mathrm{C}\right)$. Considering different veneer ceramic repair sets, there was no statistically significant difference for bond strengths after the aging process in three different repair sets. In our study, RBS values of veneer ceramic specimens with composite resin decreased after thermal cycling, but no significant difference was observed compared to control group.

In the studies, fracture surfaces were classified as adhesive, cohesive, and mixed types. ${ }^{49-51}$ Uludamar $^{52}$ and Aky1l et al. ${ }^{53}$ studied about the effects of different surface treatments on the connection between resin cement and zirconia and reported that the fractures were adhesive type in all specimens in their work. In this study, we observed that adhesive type fractures exist between zirconia specimens and composite resin.

Cohesive type fractures have been reported in several studies investigating the veneer ceramic-composite resin connection. ${ }^{28,34}$ Külünk et al. ${ }^{54}$ observed that there were only cohesive type failures in their repair process with Clearfil repair kit on IPS Empress Esthetic. All cohesive fractures were within the substructure material. Ozdemir et al. ${ }^{55}$ showed the effect of different surface treatments on veneer ceramic-composite resin bonding and reported that all specimens that used the Clearfil Repair set had cohesive fractures. In this study, we observed cohesive type fractures among the all veneer ceramic specimens. The fractured parts were formed as a result of separations on veneer ceramic surface. As a result of applying the materials in the repair kit, the bond strength between the composite resin and veneer ceramic may have exceeded the strength limit of the veneer ceramic.

If there is a large amount of cracks on the surface of 
the remaining veneer ceramic after the fracture, fracture formation may be seen again after the repairs due to the weakness of the integrity of the structure. ${ }^{56}$ Fractures that occur after intraoral repair using composites are reported to occur due to chewing forces, trauma, or incorrect bonding procedures. ${ }^{30}$ Before starting the repair process, the cause of the breakage must be determined and eliminated in order to avoid failure.

The limitations of this study can be stated as follows. Only the RBS test was applied among bond strength tests. Different surface treatments were not applied. Also, the size and shape of specimens were not similar to the clinical crown anatomy. More accurate results can be achieved by applying a mechanical cycle in addition to the thermal cycle. The use of different materials, application of different working methods, and changes in the interface surface area may change the results of the bond strength test.

\section{CONCLUSION}

Considering the composite resin and specimens in all groups, RBS values decreased after the thermal cycle application. This decrease did not create a statistically significant difference in veneer ceramic specimens. However, a significant difference was observed after the application of 12000 thermal cycles in zirconia and veneer ceramic-zirconia specimens. The highest RBS values between the specimens and composite resin were obtained in zirconia specimens and the lowest bond strength values were obtained from veneer ceramic specimens in all control and thermal cycling groups.

\section{ACKNOWLEDGEMENTS}

The authors thank Deniz Özel Erkan for his professional assistance in statistical analysis.

\section{ORCID}

Serkan Ç1nar bttps://orcid.org/0000-0001-5934-229X

Ömer Kirmalı https://orcid.org/0000-0002-4313-344X

\section{REFERENCES}

1. Guazzato M, Albakry M, Ringer SP, Swain MV. Strength, fracture toughness and microstructure of a selection of allceramic materials. Part I. Pressable and alumina glass-infiltrated ceramics. Dent Mater 2004;20:441-8.

2. Tsalouchou E, Cattell MJ, Knowles JC, Pittayachawan P, McDonald A. Fatigue and fracture properties of yttria partially stabilized zirconia crown systems. Dent Mater 2008;24:30818.

3. Anusavice K, Shen C, Rawls HR. Phillips' science of dental materials. Elsevier Health Sciences. 12th ed., Saunders Elsevier Inc., Missouri: 2013.

4. Al-Dohan HM, Yaman P, Dennison JB, Razzoog ME, Lang BR. Shear strength of core-veneer interface in bi-layered ceramics. J Prosthet Dent 2004;91:349-55.
5. Kelly JR, Tesk JA, Sorensen JA. Failure of all-ceramic fixed partial dentures in vitro and in vivo: analysis and modeling. J Dent Res 1995;74:1253-8.

6. Chung KH, Hwang YC. Bonding strengths of porcelain repair systems with various surface treatments. J Prosthet Dent 1997;78:267-74.

7. Appeldoorn RE, Wilwerding TM, Barkmeier WW. Bond strength of composite resin to porcelain with newer generation porcelain repair systems. J Prosthet Dent 1993;70:6-11.

8. Haselton DR, Diaz-Arnold AM, Dunne JT Jr. Shear bond strengths of 2 intraoral porcelain repair systems to porcelain or metal substrates. J Prosthet Dent 2001;86:526-31.

9. Ozcan M. The use of chairside silica coating for different dental applications: a clinical report. J Prosthet Dent 2002;87: 469-72.

10. Gregory WA, Moss SM. Effects of heterogeneous layers of composite and time on composite repair of porcelain. Oper Dent 1990;15:18-22.

11. Shahverdi S, Canay S, Suahin E, Bilge A. Effects of different surface treatment methods on the bond strength of composite resin to veneer ceramic. J Oral Rehabil 1998;25:699-705.

12. Thurmond JW, Barkmeier WW, Wilwerding TM. Effect of porcelain surface treatments on bond strengths of composite resin bonded to porcelain. J Prosthet Dent 1994;72:355-9.

13. Kern M, Barloi A, Yang B. Surface conditioning influences zirconia ceramic bonding. J Dent Res 2009;88:817-22.

14. Özcan M, Vallittu PK. Effect of surface conditioning methods on the bond strength of luting cement to ceramics. Dent Mater 2003;19:725-31.

15. Özcan M, Valandro LF, Amaral R, Leite F, Bottino MA. Bond strength durability of a resin composite on a reinforced ceramic using various repair systems. Dent Mater 2009;25:147783.

16. Kirmali O, Kapdan A, Kustarci A, Er K. Veneer ceramic to Y-TZP bonding: comparison of different surface treatments. J Prosthodont 2016;25:324-9.

17. Blum IR, Nikolinakos N, Lynch CD, Wilson NH, Millar BJ, Jagger DC. An in vitro comparison of four intra-oral ceramic repair systems. J Dent 2012;40:906-12.

18. D'Amario M, Campidoglio M, Morresi AL, Luciani L, Marchetti E, Baldi M. Effect of thermocycling on the bond strength between dual-cured resin cements and zirconium-oxide ceramics. J Oral Sci 2010;52:425-30.

19. Lüthy H, Loeffel O, Hammerle CH. Effect of thermocycling on bond strength of luting cements to zirconia ceramic. Dent Mater 2006;22:195-200.

20. Donovan TE. Metal-free dentistry. J Esthet Restor Dent 2005; 17:141-3.

21. Fradeani M, D’Amelio M, Redemagni M, Corrado M. Fiveyear follow-up with Procera all-ceramic crowns. Quintessence Int 2005;36:105-13.

22. Guess PC, Kulis A, Witkowski S, Wolkewitz M, Zhang Y, Strub JR. Shear bond strengths between different zirconia cores and veneering ceramics and their susceptibility to thermocycling. Dent Mater 2008;24:1556-67.

23. Freilich MA, Karmaker AC, Burstone CJ, Goldberg AJ. Development and clinical applications of a light-polymerized 
fiber-reinforced composite. J Prosthet Dent 1998;80:311-8.

24. Llobell A, Nicholls J, Kois J, Daly C. Fatigue life of veneer ceramic repair systems. Int J Prosthodont 1992;5:205-13.

25. Ozcan M. Evaluation of alternative intra-oral repair techniques for fractured ceramic-fused-to-metal restorations. J Oral Rehabil 2003;30:194-203.

26. Kamposiora P, Papavasiliou G, Bayne SC, Felton DA. Stress concentration in all-ceramic posterior fixed partial dentures. Quintessence Int 1996;27:701-6.

27. Hooshmand T, van Noort R, Keshvad A. Bond durability of the resin-bonded and silane treated ceramic surface. Dent Mater 2002;18:179-88.

28. Pameijer CH, Louw NP, Fischer D. Repairing fractured porcelain: how surface preparation affects shear force resistance. J Am Dent Assoc 1996;127:203-9.

29. Cavalcanti AN, Pilecki P, Foxton RM, Watson TF, Oliveira MT, Gianinni M, Marchi GM. Evaluation of the surface roughness and morphologic features of Y-TZP ceramics after different surface treatments. Photomed Laser Surg 2009;27:4739.

30. Ozcan M, Niedermeier W. Clinical study on the reasons for and location of failures of metal-ceramic restorations and survival of repairs. Int J Prosthodont 2002;15:299-302.

31. Shiu P, De Souza-Zaroni WC, Eduardo Cde P, Youssef MN. Effect of feldspathic ceramic surface treatments on bond strength to resin cement. Photomed Laser Surg 2007;25:2916.

32. Akyil MS, Yilmaz A, Karaalioğlu OF, Duymuş ZY. Shear bond strength of repair composite resin to an acid-etched and a laser-irradiated feldspathic ceramic surface. Photomed Laser Surg 2010;28:539-45.

33. Attia A, Kern M. Fracture strength of all-ceramic crowns luted using two bonding methods. J Prosthet Dent 2004;91:24752.

34. Leibrock A, Degenhart M, Behr M, Rosentritt M, Handel G. In vitro study of the effect of thermo- and load-cycling on the bond strength of porcelain repair systems. J Oral Rehabil 1999;26:130-7.

35. Kirmali O, Kapdan A, Harorli OT, Barutcugil C, Ozarslan MM. Efficacy of ceramic repair material on the bond strength of composite resin to zirconia ceramic. Acta Odontol Scand 2015;73:28-32.

36. Şen D, Nayır EH. Yüzey Hazırlı̆̆ının Porselen Tamir Materyallerinin Bağlantı Kuvveti Üzerine Etkisi. J Istanb Univ Fac Dent 1997;31:69-75.

37. Matinlinna JP, Vallittu PK. Bonding of resin composites to etchable ceramic surfaces - an insight review of the chemical aspects on surface conditioning. J Oral Rehabil 2007;34:62230.

38. Corazza PH, Cavalcanti SC, Queiroz JR, Bottino MA, Valandro LF. Effect of post-silanization heat treatments of silanized feldspathic ceramic on adhesion to resin cement. J Adhes Dent 2013;15:473-9.

39. Thompson JY, Stoner BR, Piascik JR, Smith R. Adhesion/cementation to zirconia and other non-silicate ceramics: where are we now? Dent Mater 2011;27:71-82.

40. Tzanakakis EG, Tzoutzas IG, Koidis PT. Is there a potential for durable adhesion to zirconia restorations? A systematic review. J Prosthet Dent 2016;115:9-19.

41. Seabra B, Arantes-Oliveira S, Portugal J. Influence of multimode universal adhesives and zirconia primer application techniques on zirconia repair. J Prosthet Dent 2014;112:1827.

42. Wolfart M, Lehmann F, Wolfart S, Kern M. Durability of the resin bond strength to zirconia ceramic after using different surface conditioning methods. Dent Mater 2007;23:45-50.

43. Demetoglu GA, Zortuk M. Effect of surface treatments on leakage of zirconium oxide ceramics. Meandros Med Dent J 2016;17:64.

44. Bailey LF, Bennett RJ. DICOR surface treatments for enhanced bonding. J Dent Res 1988;67:925-31.

45. Chang JC, Powers JM, Hart D. Bond strength of composite to alloy treated with bonding systems. J Prosthodont 1993;2: 110-4.

46. Passia N, Mitsias M, Lehmann F, Kern M. Bond strength of a new generation of universal bonding systems to zirconia ceramic. J Mech Behav Biomed Mater 2016;62:268-74.

47. Kamada K, Yoshida K, Atsuta M. Effect of ceramic surface treatments on the bond of four resin luting agents to a ceramic material. J Prosthet Dent 1998;79:508-13.

48. Matsumura H, Kato H, Atsuta M. Shear bond strength to feldspathic porcelain of two luting cements in combination with three surface treatments. J Prosthet Dent 1997;78:511-7.

49. Blatz MB, Sadan A, Arch GH Jr, Lang BR. In vitro evaluation of long-term bonding of Procera AllCeram alumina restorations with a modified resin luting agent. J Prosthet Dent 2003;89:381-7.

50. Kirmali O, Akin H, Ozdemir AK. Shear bond strength of veneering ceramic to zirconia core after different surface treatments. Photomed Laser Surg 2013;31:261-8.

51. Polat S, Cebe F, Tunçdemir A, Öztürk C, Üşümez A. Evaluation of the bond strength between aged composite cores and luting agent. J Adv Prosthodont 2015;7:108-14.

52. Uludamar A, Akalin B, Kulak Y. Surface preparations of zirconia based full ceramic restorations before cementation. Cumhuriyet Dent J 2011;14:140-53.

53. Akyil MS, Uzun IH, Bayindir F. Bond strength of resin cement to yttrium-stabilized tetragonal zirconia ceramic treated with air abrasion, silica coating, and laser irradiation. Photomed Laser Surg 2010;28:801-8.

54. Külünk T, Saraç Ş. Tam seramik sistemlerde farklı ağı içi tamir setlerinin kullanımımın tamir dayanımıma etkisi. J Ondokuz May1s Univ Fac Dent 2010;10:87-95

55. Özdemir E, Niğiz R, Zortuk M. Farklı yüzey hazırlıklarının porselen kompozit rezin bağlantısı üzerine etkisinin in-vitro araştırılması. J Gazi Univ Fac Dent 2007;24:75-82.

56. Chadwick RG, Mason AG, Sharp W. Attempted evaluation of three porcelain repair systems-what are we really testing? J Oral Rehabil 1998;25:610-5. 